
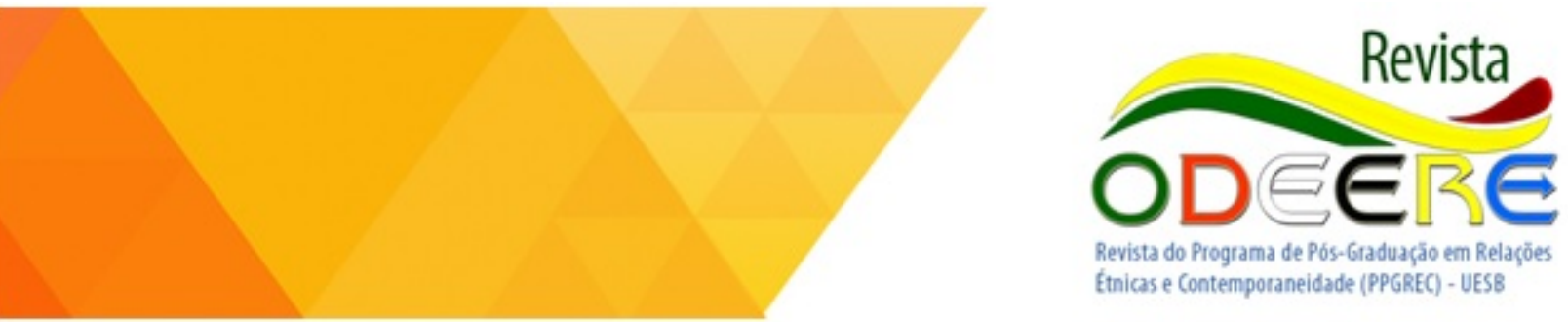

O DISCURSO DO LIVRO DIDÁTICO DE FÍSICA: por uma escolha pela diferença

\section{THE SPEECH OF} THE DIDACTIC BOOK OF PHYSICS: By a choice for the difference

\author{
Mariana Fernades dos Santos \\ Instituto Federal da Bahia (IFBA) \\ marianafernandes.ifba@gmail.com
}

Nathalia Helena Alem

Instituto Federal da Bahia (IFBA)

nathaalem@gmail.com

\author{
Jorge Ferreira Dantas Junior \\ Instituto Federal da Bahia (IFBA) \\ jorge.dantas@ifba.edu.br
}

Resumo: $O$ discurso didático que a escola vem construindo ao longo da história da educação brasileira tem em seu bojo o centralismo epistemológico eurocêntrico institucionalizado. Sendo assim, entendemos ser necessário a constante problematização em torno desses discursos na ação docente. Neste artigo, temos como objetivo analisar a forma como são discursivizadas a História e Cultura AfroBrasileiras, Africanas, e Indígenas no discurso didático do livro de Física do Ensino Médio Integrado ao Técnico em uso no IFBA, campus Eunápolis. Realizamos uma pesquisa bibliográfica por meio da análise de um corpus constituído de materialidades advindas da coleção, Compreendendo a Física, Alberto Gaspar - 3. ed. - São Paulo: Ática, 2016. Para isso mobilizamos a análise do discurso de linha francesa, as teorias fundantes desta pesquisa de perspectiva multicultural e decolonial, bem como discussões acerca do Livro Didático, esse aparato didático tão presente nas salas de aula e tão pouco consensual. Os resultados apontam que o discurso didático da coleção analisada, não se movimenta para a efetivação de fato da legislação específica do Ensino de História e Cultura Afro-brasileira na rede regular de educação básica. Por isso podemos afirmar que há necessidade de ampliação no plano conceitual e epistemológico do que significa construir uma proposta didática sob a perspectiva racial, que considere para o ensino de Física, as epistemologias africanas e indígenas que potencializam a descolonização deste artefato cultural

Palavras-chave: Relações étnico-raciais. Livro didático. Descolonização. Discurso didático.

Abstract: The didactic discourse that the school has been building throughout the history of Brazilian education has in its core institutionalized Eurocentric epistemological centralism. Therefore, we understand that it is necessary to constantly question these discourses in the teaching activity. In this article, 
we have the objective of analyzing how AfroBrazilian, African, and Indigenous History and Culture are discursed in the didactic discourse of the Physics Book of High School Integrated with the Technician in use at the IFBA, Eunápolis campus. We carried out a bibliographical research by means of the analysis of a corpus constituted of materialidades coming from the collection, Understanding the Physics, Alberto Gaspar - 3. ed. - São Paulo: Attica, 2016. For this we mobilize the analysis of French line discourse, the founding theories of this research of multicultural and decolonial perspective, as well as discussions about the Didactic Book, this didactic apparatus so present in classrooms and so little consensual The results point out that the didactic discourse of the collection analyzed does not move towards the actual realization of the specific legislation of the Teaching of AfroBrazilian History and Culture in the regular network of basic education. Therefore we can affirm that there is a need for a conceptual and epistemological extension of what it means to construct a didactic proposal from a racial perspective, which considers for the teaching of Physics the African and indigenous epistemologies that enhance the decolonization of this cultural artefact.

Keywords: Ethnic-racial relations. Textbook. Decolonization. Didactic speech.

Não nos enganemos: a imagem que fazemos de outros povos, e de nós mesmos está associada à História que nos ensinaram quando éramos crianças. Ela nos marca para o resto da vida. Sobre essa representação, que é para cada um de nós uma descoberta do mundo e do passado das sociedades, enxertam-se depois opiniões, ideias fugazes

ou duradouras, como um amor... mas permanecem indeléveis as marcas das nossas primeiras curiosidades, das nossas primeiras emoções. Marc Ferro (1983: 11)

\section{Olhar a história para problematizar o presente}

$A^{1}$ cultura brasileira, bem como a de toda a América Latina, é formada por uma estrutura triangular característica do período de colonização resultando da mescla de tradições ameríndias, europeias e africanas. Entretanto, o que ocorre é uma supervalorização de uma determinada cultura em detrimento de outras, ficando privilegiada uma determinada região e um momento da evolução da humanidade. O que não ocorreu sem um sentido e intencionalidade, carregando em si uma perspectiva de valoração e desvalorização de sujeitos, culturas e suas histórias.

Nas últimas décadas, no Brasil e no mundo, intensas mobilizações por mudanças se efetivaram por meio de lutas diversas dos movimentos sociais, e culminaram em leis a favor dos processos de descolonização das ações educacionais. Processos que têm causado muitas tensões e desafios na educação brasileira. Embora possam se vislumbra muitos avanços, ainda persiste um ideal étnico-racial no Brasil que valoriza as referências europeias de sua cultura normatizando e

\footnotetext{
${ }^{1}$ D’AMBROSIO, Ubiratan. Etnomatemática: elo entre as tradições e a modernidade. Belo Horizonte: Autêntica, 2001. 112p. (Coleção Tendências em Educação Matemática).
} 
naturalizando a desigualdade racial, bem como a desvalorização da religiosidade, estética, corporeidade e musicalidade africana principalmente e de outras etnias.

Apesar da África configurar-se como berço da humanidade e do desenvolvimento civilizatório, sua história e cultura ainda não se constitui em referência, nem mesmo nos estudos que deveriam levar em conta as mudanças da/na natureza e da vida. Tomando como premissa que todos os seres humanos evoluíram de uma ancestralidade comum, oriunda na África, percebe-se contudo, que a comunidade afro-descendente, sua cultura e história ainda hoje, sofre com o preconceito, o descaso e a falta de oportunidades; fenômeno social esse que teve origem no contexto vivido desde a época da colonização ${ }^{2} 34$.

Por conta disso é legitima e necessária a luta por diferentes frentes, modos e espaços contra a representação negativa dos povos negros e a favor da visibilidade da cultura africana, afrobrasileira, indígena, ameríndia e mestiça. Nesse sentido, compreendemos que a Escola e todos os seus elementos (no nosso caso aqui o livro didático e possibilidades de usos) atuam como um microcosmo da sociedade tendo o poder de influenciar e interferir na formação das/dos estudantes e no seu posicionamento frente ao mundo.

$\mathrm{O}^{5}$ homem é um ser histórico, constituído socialmente, que aprende por meio da interação com o seu meio: indivíduos pertencentes ao mesmo local e tempo. Desse modo, o livro didático, um importante instrumento de poder, produção e reprodução de conhecimento, e pouco consensual, mas que no caso brasileiro é, em muitos contextos, o único material utilizado pelos/pelas professores/as na maioria das escolas brasileiras, bem como os únicos impressos que adentram as casas dos alunos e suas famílias, urge ser problematizado. Uma vez que os seus conteúdos necessitam contemplar a perspectiva da diversidade e da diferença, para que assim se configurem em aparatos didáticos mais eficientes e apropriados para efetivação de uma educação que rompa com essa perspectiva eurocêntrica historicamente, construída e instituída no interior do espaço escolar.

Embora consideremos os limites do alcance dos livros didáticos frente à propagação e/ou desconstrução de estereótipos racistas ou o privilégio de etnias em detrimento de outras, consideramos também que esse aparato didático é utilizado por muitas crianças e adolescentes estudantes da Educação Básica, por isso a necessidade de problematizarmos. Importante ressaltar

\footnotetext{
${ }^{2}$ SILVA, M. L.(org.) Ciência, raça e racismo na modernidade. Santa Cruz do Sul: EDUNISC, 2009.

${ }^{3}$ CAVALLEIRO, Eliane (Org.). Racismo e anti-racismo na educação. Repensando nossa escola. São Paulo: Summus, 2001.

${ }^{4}$ ANDRÉ, M. da C.. O Ser Negro - A construção da subjetividade em afro brasileiros. Brasília, LGE Editora, 2008. 268 $\mathrm{p}$

${ }^{5}$ FREIRE, Paulo. Educação e atualidade brasileira. Instituto Paulo Freire, 2001.
} 
que no caso das áreas de conhecimento das Ciências da Natureza, que envolve a Física, essa consideração precisa ser ainda mais problematizada, diante do histórico de formação docente e ensino, voltados muito mais ao formalismo matemático e conteúdos conceituais e menos foco para a ciência enquanto prática social, de maneira mais humanizada.

À guisa desse pensamento, a Lei 10.639/03, existe há mais de dez anos e é evidente a dificuldade por parte das instituições escolares, nos mais diversos níveis, em implementar uma educação para reeducar as relações étnico-raciais no país, afinal, como bem afirmam as Diretrizes Curriculares Nacionais para a Educação das Relações Étnico-Raciais:

Se não é fácil ser descendente de seres humanos escravizados e forçados à
condição de objetos utilitários ou a semoventes, também é difícil descobrir-se
descendente dos escravizadores, temer, embora veladamente, revanche dos que,
por cinco séculos, têm sido desprezados e massacrados. Para reeducar as relações
étnico-raciais, no Brasil, é necessário fazer emergir as dores e medos que têm sido
gerados. É preciso entender que o sucesso de uns tem o preço da marginalidade e
da desigualdade impostas a outros. E então decidir que sociedade queremos
construir daqui para frente ${ }^{6}$.

Diante disso, neste artigo, temos como objetivo analisar a forma como são discursivizadas a História e Cultura Afro-Brasileiras, Africanas e Indígenas no discurso didático do livro de Física do Ensino Médio Integrado ao Técnico, utilizado no IFBA, campus Eunápolis. Realizamos uma pesquisa bibliográfica por meio da análise de um corpus constituído de materialidades advindas da coleção, Compreendendo a Física, Alberto Gaspar - 3. ed. - São Paulo: Ática, 2016. Para isso mobilizamos a análise do discurso de linha francesa, as teorias fundantes desta pesquisa de perspectiva multicultural e decolonial, bem como discussões acerca do Livro Didático.

\section{Sobre a diferença e o discurso do livro didático na escola}

A introdução da educação para as relações étnico-raciais no Brasil é marcada pela luta do movimento Movimento Social Negro e a Lei 10639/2003, que tornou obrigatória, para todos os estabelecimentos de ensino, a inclusão da História e Cultura Africana e Afro-brasileira como tema nos componentes curriculares. Nessa $v^{7}{ }^{7}$, o papel da discussão sobre cultura negra na educação consiste em "ressignificar e construir representações positivas sobre o negro, sua história, sua cultura, sua corporeidade e sua estética" ${ }^{8}$.

\footnotetext{
${ }^{6}$ BRASIL. Ministério da Educação e Cultura. Diretrizes Curriculares Nacionais para Educação das Relações ÉtnicoRaciais e para o Ensino de História e Cultura Afro-brasileira e Africana. Brasília: MEC, 2004.

${ }^{7}$ GOMES, Nilma Lino. Relações étnico-raciais, educação e descolonização dos currículos. Currículo sem Fronteiras, v. 12, n.1, p. 98-109, jan/ abr., 2003.

8 Ibdem.
} 
Para além de força de lei e diretrizes o ensino da Cultura e História Africana e Afro-brasileira, assim como a incorporação das histórias e culturas dos povos indígenas com a Lei $11645^{9}$ representam a necessidade de superar as mazelas históricas que o silenciamento dos conteúdos referentes a estes povos causou na sociedade brasileira. Isso porque os sistemas educacionais em geral, apesar de alguns avanços, normatizam o discurso pedagógico, que se propõe didático, baseado no etnocentrismo. Com essa prática, invisibilizam de seus currículos as formas de vida produzidas pela interação entre as diferentes culturas que compõem a nação brasileira, deixando a responsabilidade aos estudantes negros e indígenas a luta por sua própria emancipação intelectual e social, naturalizando um modelo de educação que não contempla a diversidade humana.

Esses discursos normatizantes se propagam nos espaços escolares e na sociedade de forma geral, como consequência, nos repertórios dos seus artefatos culturais, como os livros didáticos. Por isso é importante indagarmos sobre as permanências e movimentações dos discursos presentificados nesses recursos didáticos, já que ${ }^{10}$ as diferenças discursivas são de ordem linguística, antropológica e psicanalítica, havendo uma complexidade de fatores e enunciados para serem desvelados nas relações sociais, sejam elas relações interpessoais e/ou institucionais.

É preciso que esse discursos sejam problematizados, mas que isso não fique apenas na ideia de constatar as diferenças culturais e ou privilégio de uma em relação a outras, mas que sejam mobilizadas ações em prol de mudanças. O autor apresenta para esse fim, três estratégias: Ireivindicar políticas de representação; II- atribuir positividade em atributos anteriormente negativos à etnia africana; III- realizar a positivação do corpo negro (estética diaspórica) $)^{11}$.

Nesse sentido, entendemos que os discursos são elaborações histórico-culturais que se materializam na relação entre ideologia e livro didático de maneira que "a ideologia dominante tem a função de mistificar os objetivos reais de exploração e discriminação sociais, a fim de manter o ethos capitalista, que favorece a classe dominante" ${ }^{12}$.

$O s^{13}$ discursos didáticos são conjuntos de asserções apresentadas como objetivamente "verdadeiras". Nessa lógica, o sujeito da enunciação se apaga afim de permitir ao/a leitor/a identificar-se com ele. Uma prática discursiva que não visa a persuasão, afinal, ela já foi feita. Para

\footnotetext{
${ }^{9}$ BRASIL. Lei 11.645/08 de 10 de Março de 2008. Diário Oficial da União, Poder Executivo, Brasília.

${ }^{10}$ HALL, S. Da Diáspora: Identidades e mediações culturais. Minas Gerais: UFMG, 2003.

${ }^{11}$ Ibdem.

${ }^{12}$ NOSELLA, Maria de Lourdes Chagas Deiro. As belas mentiras: a ideologia subjacente aos textos didáticos. 8. ed. São Paulo: Moraes, 1978.

${ }^{13}$ ORLANDI, Eni Puccinelli. Gestos de leitura: da história no discurso. (Org.) et al. 4ed. Campinas, SP: Editora da Unicamp, 2014.
} 
a autora, esse discurso, formula asserções que não se opõem a outras, isso porque o Discurso Didático (DD) informa a "verdade", por isso não há confronto. O DD supõe um vazio enunciativo do seu/sua leitor/a que deve ser integrado ao seu próprio discurso. Nessa perspectiva, esse discurso, enquanto didático se apresenta como um conjunto ordenado de enunciados, sobre os quais o sujeito leitor/a deverá se apropriar e buscar suas conclusões (aprendizagens - grifo nosso).

A análise de discurso $(A D)^{14}$ busca compreender como um objeto simbólico produz sentidos, como ele está investido de significância para e por sujeitos. Dessa forma, condições de produção do discurso, são relevantes que segundo a autora, é aquilo que determina o que pode e deve ser dito, quem diz, para quem diz, como diz e aonde diz. Nesse processo um jogo de imagens condiciona o dizer e seus sentidos, o que a AD chama de formações imaginárias. Assim, os sujeitos do discurso estão investidos de representações imaginárias que os situam em determinado lugar na estrutura social. Essas formações imaginárias demarcam o lugar que o enunciador e o coenunciador do discurso atribuem a si mesmo e ao outro, a imagem que fazem deste lugar que ocupam e a imagem do referente. Portanto, a materialização do discurso, por meio do texto, presentificará nos dizeres: (i) a imagem que quem diz tem de si mesmo (ii) a imagem de quem escuta ou lê e (iii) a imagem do que diz.

Para a Análise do Discurso Francesa (ADF), os sentidos dos discursos se constituem a partir das interpretações que deles se realizam, as quais dependem da mesma forma, das diversas maneiras e materialidades em que a linguagem dispõe tais sentidos ${ }^{15}$. Sendo assim, compreendemos que os mais distintos tipos de discursos não apresentam dizeres explícitos, dessa forma, por meio dos princípios e procedimentos da ADF, visamos desvelar os modos de funcionamento dos discursos, focando, sobretudo, para aquilo que está silenciado, que não se encontra visível em suas superfícies, até porque "a linguagem estabiliza o movimento dos sentidos. No silêncio, ao contrário, o sentido e sujeito se movem largamente" ${ }^{16}$. Por isso que interpretar em ADF é tentar ler/ver por meio da opacidade, tendo em vista que, de acordo com essa perspectiva teórica, a linguagem não é transparente.

Nesse movimento de leitura é possível perceber as representações sociais, considerando $q^{17} \mathrm{e}^{17}$, a representação social é indissociável à vida cotidiana, construída eventualmente por meio de enunciados e imagem socialmente compartilhados. Assim, é imprescindível a dialética entre o

\footnotetext{
${ }^{14}$ ORLANDI, Eni P. Análise do discurso: princípios e procedimentos. Campinas: Pontes, 1999.

${ }^{15}$ ORLANDI, Eni P. Interpretação; autoria, leitura e efeitos do trabalho simbólico. $4^{\mathrm{a}}$ Ed. Campinas: Pontes, 2004.

${ }^{16}$ ORLANDI, Eni Puccinelli. As formas do silêncio: no movimento dos sentidos. Campinas, SP: Editora da Unicamp. 6 . ed., 2013.

${ }^{17}$ JODELET, Denise. As representações sociais. Ed: UERJ. Rio de Janeiro, 2001.
} 
discurso contido no livro didático e a representação étnico-racial, uma vez que, está poderá ser discutida a partir do viés da interpretação acerca da realidade circundante. Porquanto a noção de raça e etnia é mediada pelas representações sociais, já que, mobiliza o diálogo do mundo com o outro, pois está associada aos diversos posicionamentos do sujeito do discurso.

A efetiva implementação da lei 10.639/2003 solicita mudanças curriculares nas instituições de ensino e essas mudanças são complexas e transcendem trabalhar os conteúdos tradicionais da escola, para de maneira transversal, abordar temas ligados a História e Cultura Afro-Brasileira e Africana. Essa mudança deve estar posta no Projeto Pedagógico da escola, de modo que o currículo proposto seja dinâmico e flexível, permitindo o ajuste do fazer pedagógico às particularidades de cada aluno ${ }^{18}$.

A compreensão para implementação da lei suscitam diferentes formas que perpassam pela revisão de conteúdo, de currículos e de práticas pedagógicas, essas formas estão direcionadas a defesa da criação de uma disciplina específica para abordagem da temática; a ideia de que a temática deve ser abordada somente nos currículos das disciplinas de história, educação artística e literatura; e ainda, a obrigatoriedade de que em todas as disciplinas o tratamento transdisciplinar do conteúdo da lei ocorra. Nos aliamos a esta última compreensão, mesmo considerando que as duas anteriores também podem ser caminhos para aplicação da lei e institucionalização da Educação para as Relações Étnico-Raciais - ERER.

Por $^{19}$ muito tempo a presença dos negros no livro foi marcada pelo estereótipo e pela caricatura, fazendo com que as crianças negras fossem excluídas e inferiorizadas. O livro ao fazer isso reforça a ideologia do branqueamento, que por meio do livro didático impõe como condição de existência o centralismo eurocêntrico, atribuindo as características do branco como referência central. Em relação ao Livro Didático de Física (LDF) caracteriza-se como um complexo artefato de importante poder cultural, constituído pela associação do discurso científico, pedagógico e midiático, em prol da disseminação de teorias educacionais e científicas, importante na construção do conhecimento dos estudantes, por carregar características da linguagem científica e escolar ${ }^{20}$.

Por esse viés, o LDF tem como função mobilizar conhecimentos escolares, em que os contextos abordados por este recurso são adaptações de conhecimentos científicos, já que a linguagem

\footnotetext{
${ }^{18}$ CANEN, A.; MOREIRA, A. F. B. (orgs.). Ênfases e Omissões no currículo. Campinas, SP: Papirus, 2001.

${ }^{19}$ SILVA, Paulo Vinicius Baptista. Racismo em livros didáticos: estudos sobre negros e brancos em livros de língua portuguesa. Belo Horizonte: Autêntica, 2008.

${ }^{20}$ GARCIA, P. S.; BIZZO, N. A pesquisa em livros didáticos de ciências e as inovações no ensino. Revista Educação em Foco, v. 13, n. 15: p. 13-35, Belo Horizonte, jul. 2010.
} 
deste aparato pedagógico é oriunda do contexto científico e inserida no contexto dos estudantes, e esse processo de adaptação define a transposição didática como a principal característica do $\operatorname{LDF}^{21}$, mas compreendemos que o processo de construção é algo maior que a transposição em si. Porém, o que temos presenciado é o LDF com outras características que estão menos preocupadas com a transposição didática, e sim com a interpretação da construção do conhecimento científico a partir de uma visão exclusivamente empirista-indutivista. Esse formato, reforça a prática linear e formalista recorrente no ensino de Física, que presa mais pelo conteudísmo conceitual e cientificista.

O livro didático, seja ele de Física ou de outro componente curricular, possui uma história relativamente curta nos processos de escolarização no Brasil, especialmente se compreendermos que é

um artefato impresso em papel, que veicula imagens e textos em formato linear e sequencial, planejado, organizado e produzido especificamente para uso em situações didáticas, envolvendo predominantemente alunos e professores, e que tem a função de transmitir saberes circunscritos a uma disciplina escolar ${ }^{22}$.

Assumindo essa definição como referência, compreendemos que, livros organizados especificamente para o uso no espaço escolar, são instrumentos pedagógicos construído a menos de um século em nosso país. Assim, livros que tem por função didatizar conhecimentos e promover o trabalho com componentes curriculares específicos, fazem parte da cultura escolar recente. Não muito diferente da implantação das políticas para o livro didático que "se constituíram juntamente com as políticas que estruturaram a escola brasileira como sistema, a partir de 1930." 23

A sua distribuição em larga escala é ainda mais recente, e só se consolida com o Programa Nacional do Livro Didático, o PNLD, criado em 1985, em meio ao processo de redemocratização e respondendo as reivindicações e lutas de diferentes setores da sociedade. Essa política pública, tornou-se política de estado ${ }^{24}$, durante o governo Luis Inácio Lula da Silva, no ano de 2010, e hoje beneficia estudantes de todo ensino fundamental e médio, de norte a sul do pais, e como já foi indicado, oportuniza, muitas vezes, o único contato com a cultura letrada e impressa a milhões de

\footnotetext{
${ }^{21}$ DOMINGUINI, L. Fatores Que Evidenciam A Necessidade De Debates Sobre O Livro Didático, 2010. Trabalho apresentado em V CINFE- Congresso Internacional de Filosofia e Educação, Caxias do Sul, mai. 2010.

${ }^{22}$ OLIVEIRA, Margarida Maria Dias de. Livros didáticos de história: pesquisa,ensino e novas utilizações deste objeto cultural. IN: Série: o livro didático em questão. Salto para o futuro. Rio de Janeiro: Empresa Brasileira de Comunicação, (08/05/ 2006-12/05/2006).

${ }^{23}$ ROCHA, H.A.B.; REZNIK, L.; MAGALHÃES, M.S. (Orgs.) A história na escola: autores, livros e leituras. Rio de Janeiro: Ed. FGV, 2009.

24 Como política de Estado essa política pública não pode ser extinta, ou diminuída, conforme as perspectivas deste ou daquele governo.
} 
alunos e suas famílias.

O processo de escolha das obras era todo disciplinado por editais lançados pelo Ministério da Educação ${ }^{25}$. Esses instrumentos legais suleadores de todo processo construídos e lançados por equipes técnicas dos diferentes componentes curriculares, eram compostas por profissionais das mais diversas universidades brasileiras, com produção reconhecida nos campos de suas ciências de referência e do ensino de seu componente curricular, em conjunto com os técnicos do Ministério. Entre o lançamento dos primeiros editais e a chegada das obras na escola havia um intervalo que girava em torno de dois anos.

Os editais eram construídos tendo como referências principais os instrumentos legais que normatizam, balizam e orientam a educação brasileira, como: Parâmentros Curriculares Nacionais, Diretrizes Curriculares Nacionais, Estatuto da Criança e do Adolescente, as Lei no 10639/03 e 11.645/08, dentre muitas outras. Toda a metodologia de avaliação, desde a composição, trabalho, instrumentos de avaliação e prazos estavam disciplinados nos editais e eram públicos. Guiavam o Ministério da Educação, as equipes técnicas, equipes de avaliação nas universidades e as editoras. Muitos são os trabalhos que, nos últimos anos, investigam e discutem os processos de avaliação desses aparatos didáticos, tão controversos e tão presentes no cotidiano das escolas, especialmente as públicas, de nosso país. ${ }^{26} 27$

Nesse processo as universidades cumpriam um papel importante, para não dizer central, construindo os editais, (dentro das possibilidades e parâmetros de nossa legislação é bom que se indique), que suleavam a avaliação, selecionando e formando as equipes que iriam efetivar as avaliações dos LD, seja de Física, ou de qualquer outro componente curricular, bem como a construção dos Guias para apreciação e escolha do LD pelos professores da rede de todo país.

As equipes de avaliadores após serem escolhidas ${ }^{28}$, treinadas iniciavam um processo de avaliação balizado pelos editais, num processo de duplo cego, em que dois sujeitos avaliavam sem saber a mesma obra despersonalizada, e com o auxílio de um coordenador que atuava como mediador. Depois de um determinado prazo, as duplas deveriam entregar as suas avaliações

\footnotetext{
${ }^{25}$ Estamos usando o tempo passado porque o processo passou por consideráveis mudanças desde 2017, no entanto, o processo que disciplinou e orientou a avaliação e aprovação da coleção analisada é a descrita acima.

${ }^{26}$ ROCHA, H.A.B.; REZNIK, L.; MAGALHÃES, M.S. (Orgs.) A história na escola: autores, livros e leituras. Rio de Janeiro: Ed. FGV, 2009.

${ }^{27}$ OLIVEIRA, M.M.D.; OLIVEIRA, A.F.B. (Orgs.) Livros didáticos de História: escolhas e utilizações. Natal, RN: EDUFRN, 2009.

${ }^{28}$ Esse processo de escolha das universidades e suas equipes variou durante as décadas de 1990 e 2000, sem mudanças nas diretivas centrais, que exigiam a formação inicial no componente curricular da equipe que iria participar, e especialmente o comprometimento com o sigilo ao longo do processo. Não teríamos tempo, nem seria o objetivo descrever essas mudanças no presente artigo, mas apenas situar a ação dos sujeitos que fazem esse trabalho, bem como os limites que esses possuem.
} 
individuais e iniciar o processo de consolidação de uma avaliação conjunta. Após a finalização do processo a obra era aprovada ou excluída. As aprovadas iriam compor o Guia, com a confecção de uma resenha que a apresentava, no caso de exclusão, um parecer deveria ser construído dentro de uma perspectiva de sustentação jurídica, para servir de instrumento nas contestações futuras das editoras que sempre ocorriam nestes casos.

A avaliação dos LDF, e de todos os outros, deveriam observar as questões referentes a área, portanto a Física, as questões Pedagógicas, Gráficas, da Legislação (se não haviam o descumprimento e/ou infração das leis que normatizam não apenas a Educação, mas o sistema legal brasileiro) e do Manual do Professor. No acaso deste último componente, muitos dos trabalhos que avaliam os LD não discutem devidamente sua importância.

Segundo os últimos editais do PNLD, o Manual do Professor (MP) deve ultrapassar a condição de local de respostas do Livro do Aluno, deve apresentar potencialidades para o trabalho com a disciplina, e se converter em elemento importante de colaboração para formação continuada docente. Dessa forma, deve apresentar possibilidades de atividades, projetos, textos para qualificar o trabalho com a disciplina e do trabalho docente. O MP para efeitos legais e de categorização é a obra que compreende o LD mais a parte específica com as atividades e seus gabaritos, discussões teóricas, apresentação do livro e de sua proposta, bem como potencialidades para o trabalho com temáticas variadas e proposta de projetos. O Manual do Professor do Livro de Física, nesse sentido poderia se converter em instrumento potente para estimular e qualificar o debate sobre e de como trabalhar com um ensino da disciplina que ultrapassasse uma discussão conteudista, incorporasse e afirmasse aspectos da história e cultura dos povos de África e da população afrodescendente no Brasil e no mundo.

Apesar de todos os esforços mobilizados para a melhoria do LDF, até o momento, ainda ocorre o tratamento dado ao conteúdo presente nesse livro, de maneira equivocada, sendo praticada a visão do conhecimento científico como um produto acabado, elaborado por mentes privilegiadas, desprovidas de interesses político-econômicos e ideológicos, ou seja, que apresenta o conhecimento sempre como verdade absoluta, desvinculado do contexto histórico e sociocultural. ${ }^{29}$

Essa visão epistemológica de ciência, presente em muitos LDs da área das ciências naturais, e seus Manuais do Professor, principalmente, fortalecem a manutenção de estereótipos da física como ciência estática, exata, e acabada em si mesma, produzida por cientistas considerados

\footnotetext{
${ }^{29}$ MEGID NETO J. ; LOPES, B. B. G.; Livros Didáticos De Física E As Inovações Da Pesquisa Em Educação Em Ciências, 2009. Trabalho apresentado em XVIII SNEF-Simpósio Nacional de Ensino de Física, Vitória, 2009.
} 
importantes por serem masculinos, brancos e europeus, que seguem um único método científico, sendo ele o único confiável, deixando a lacuna do ensino de Filosofia e História das Ciências, referência de conteúdos a serem contemplados recomendados por orientações nacionais para o Ensino de Física, como no caso das Orientações Curriculares Nacionais - Ciências Naturais - Física. A aderência dessa recomendação possibilitaria a problematização de que a produção do conhecimento, seja ele científico ou não, é humana, bem como a visibilidade e protagonismo dos povos ancestrais como é o caso da astronomia indígena e africana.

\section{O que representa o livro didático de Física em uso na escola?}

Realizamos neste estudo uma pesquisa Quali-quantitativa que envolve os métodos qualitativo e quantitativo ${ }^{30}$ e modalidade bibliográfica, em que analisamos um corpus constituído por materialidades oriundas dos três livros da coleção Compreendendo a Física, Alberto Gaspar 3. ed. - São Paulo: Ática, 2016.

Selecionamos essa coleção por ter sido a escolhida e estar em uso nos cursos do Ensino Médio Integrado do IFBA, campus de Eunápolis, logo, por sermos docentes desses cursos e comprometidos com a produção de conhecimento interdisciplinar e integrado ${ }^{31}$, entendemos ser importante e necessário, refletir sobre os recursos utilizados na ação docente. O Livro Didático (LD) e o seu MP para nós não deve ser o recurso privilegiado nas práxis educacional, ele deve ser compreendido como mais um recurso entre tantos outros possíveis. Além disso, é preciso utilizá-lo de forma crítica, compreendendo que este está a serviço da "partitura" anteriormente composta pelo professor, para o ensino da física, em um dado local, tempo e com sujeitos específicos.

Mobilizamos para essa análise um referencial teórico-metodológico da Análise de Discurso francesa, bem como as teorias fundantes deste estudo, de perspectiva decolonial e multicultural, articuladas às discussões do Livro Didático. O percurso metodológico da pesquisa movimenta-se segundo a questão de como são discursivizadas a História e Cultura Afro-Brasileiras, Africanas e Indígenas no discurso didático do livro de Física do Ensino Médio Integrado ao Técnico, utilizado no IFBA, campus Eunápolis.

A análise está organizada nos três livros da coleção respectivamente, contemplando a Dimensão gráfica, em que fizemos a contagem do quantitativo de figuras e imagens relacionadas às representações étnicas-raciais, de modo que pudemos constatar se há ou não o privilégio e/ou

\footnotetext{
${ }^{30}$ FILHO, J. Camilo dos; GAMBOA, Silvio Sánchez. Pesquisa educacional: quantidade-qualidade. 4. ed. São Paulo: Cortez, p.13-59, 2001.

${ }^{31}$ AIRES, Joanez A. Integração Curricular e Interdisciplinaridade: sinônimos?. Educ. Real., Porto Alegre, v. 36, n.1, p. 215-230, jan./abr., 2011.
} 
hierarquização dessas representações sociais ${ }^{32}$. Na Dimensão organizacional, analisamos como os conteúdos estão dispostos e qual o foco dado. Na sequência, na dimensão Pedagógica, tratamos sobre como e o que as atividades e o projetos propostos pelo LD e o MP, preconizam em relação a diversidade e diferença. Analisamos também o LD de Física para o aluno e o MP, para o professor, se esses dois aparatos cumprem com seus papeis nos aspectos pedagógicos e didáticos na perspectiva do objetivo deste trabalho.

Iniciando as análises do Livro 1, Compreendendo a Física - Volume 1 - Mecânica direcionado ao primeiro ano do Ensino Médio, na dimensão Gráfica, no total de 56 imagens/figuras de pessoas que são utilizadas para ilustrar exemplos de fenômenos físicos ou de questões de exercícios, em grande parte retratam o estereótipo branco. Até mesmo imagens/figuras de mãos manipulando objetos ou parte do corpo humano, são de pessoas da etnia branca. Sendo que o total das imagens/figuras contabilizadas, apenas 3 tem participações de pessoas não-brancas (ver tabela 1). Das ilustrações/imagens contabilizadas, algumas foram deixas de fora por conter imagens que envolvem figuras históricas como: cientistas, gravuras de livros e/ou quadros antigos etc.

\begin{tabular}{cccc} 
& \multicolumn{2}{c}{ IMAGENS DA REPRESENTAÇÃO ÉTNICO-RACIAL DO LIVRO } & \\
& Corpo inteiro & Parte do corpo & Total \\
\hline Brancos & 40 & 13 & 53 \\
\hline Não-brancos & 3 & 0 & 3 \\
\hline & & Total & 56 \\
\hline
\end{tabular}

Tabela 1 - Criação dos autores

Na seção Conexões - Arte e Ciência: a física do balé, as imagens que são utilizadas para ilustrar a discussão sobre equilíbrio e movimento, se limitam a Europa com bailarinos do balé da Ucrânia. Sendo que poderiam também mencionar o balé folclórico da Bahia, por exemplo, que contemplam o assunto abordado nessa seção.

Na seção "A energia e suas formas", as duas figuras centrais que tentam ilustrar o tema são duas atletas: uma ucraniana em uma prova de arremesso de peso, no campeonato mundial de atletismo em Doha, Catar, 2015 (imagem 1) e uma britânica em uma prova de arco e flecha, nos jogos olímpicos de Pequim, China, 2008 (imagem 2). Apesar da contemplação de gênero feminino, isso é um importante avanço, principalmente na Física, o livro deveria contemplar a Lei 11.645/08 com imagens dos jogos dos povos indígenas, como as modalidades arco e flecha; cabo de guerra; corrida com tora etc.

\footnotetext{
${ }^{32}$ JODELET, Denise. As representações sociais. Ed: UERJ. Rio de Janeiro, 2001.
} 


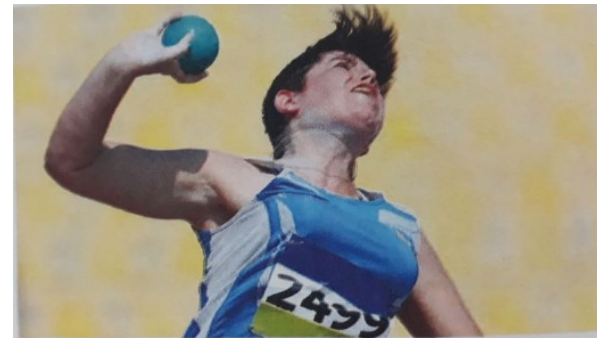

Imagem 1 - Livro 1, p.182

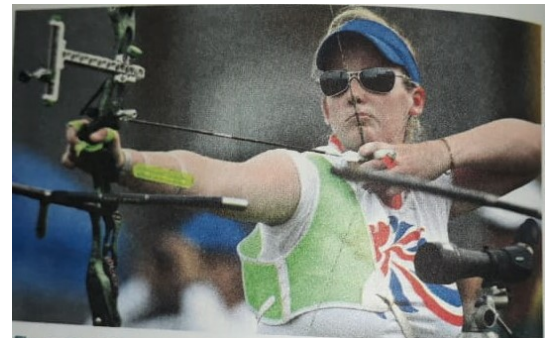

Imagem 2 - Livro 1, p.182

Na seção "A Física e a nossa saúde", segue em ilustrar, com fotos, médico e paciente brancos, bem como a manipulação de instrumento de pressão feita por uma pessoa da mesma etnia branca (imagens 3 e 4). Essa representação tem relação direta com a ideia posta no imaginário coletivo de que médicos devem ser homens e brancos, até mesmo pelo histórico social de oportunidades tidas por esta etnia em relação a outras, diante das desigualdades e diferenças produzidas, que culminam na distinção de classe.

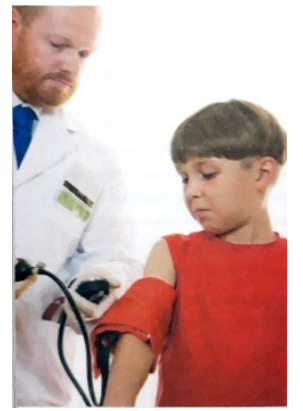

Imagem 3 - Livro 1, p.276

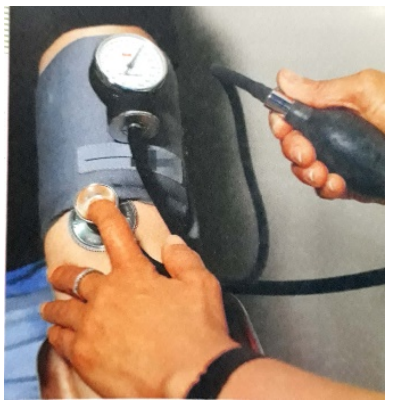

Imagem 4 - Livro 1, p.277

Na perspectiva da análise francesa o discurso tem uma relação intrínseca à exterioridade que o constitui, sua constituição transita em busca da sua completude por meio dos sentidos. $\mathrm{O}^{33}$ texto é materialidade de um movimento de forças externa e interna. "O texto é a parte visível ou material de um processo altamente complexo que inicia em outro lugar: na sociedade, na cultura, na ideologia, no imaginário". ${ }^{34}$ Dessa forma, as condições de produção de um discurso são importantes para a $A D$, porque é a partir delas que podemos afirmar que no LD de Física em análise, são priorizadas apenas uma etnia, justamente por conta das condições históricas de produção desse artefato que reproduz as ideologias sociais de visão de mundo, ou seja, de naturalização do racismo.

Sobre isso, retomamos o que já foi dito aqui sobre representação social que é indissociável à vida cotidiana, construída por meio de enunciados, imagem socialmente compartilhados,

\footnotetext{
${ }^{33}$ BENETTI, Marcia. Análise do discurso em jornalismo: estudo de vozes e sentidos. In: LAGO, Cláudia; BENETTI, Marcia (org.). Metodologia de pesquisa em jornalismo. Petrópolis: Vozes, 2007.

${ }^{34}$ Ibdem.
} 
materializados no LDF, por meio do privilégio de um referencial cultural, em detrimento de outros $^{35}$.

A análise do Livro 2, Compreendendo a Física - Volume 2 Ondas, Óptica e Termodinâmica direcionado ao segundo ano do Ensino Médio, segue o mesmo conceito do livro anterior. Também não foram contabilizadas imagens de personalidades históricas porque diante dos fatos abordados, dos sujeitos indicados para situar contextos históricos, as escolhas foram de pessoas brancas no geral. Não há uma indicação de possíveis descobertas ou criações feitas por pessoas de outras etnias.

\begin{tabular}{cccc}
\multicolumn{5}{c}{ IMAGENS DA REPRESENTAÇÃO ÉTNICO-RACIAL DO LIVRO 2 } \\
\hline & Corpo inteiro & Parte do corpo & Total \\
\hline Brancos & 21 & 28 & 49 \\
\hline Não-brancos & 2 & 0 & 2 \\
\hline & & Total & 51 \\
\end{tabular}

Tabela 2 - Criação dos autores

Devido a temática(manipulação de objetos e instrumentos de mediação para experimentos físicos, relacionados aos conteúdos, Ondas, Óptica e Termodinâmica) do livro, a quantidade de imagens de mãos manipulando objetos é maior em relação as de corpo inteiro, mas seguindo o Livro 1, todas as imagens de mãos são de etnia branca (imagens 5 e 6), como vemos na tabela 2.

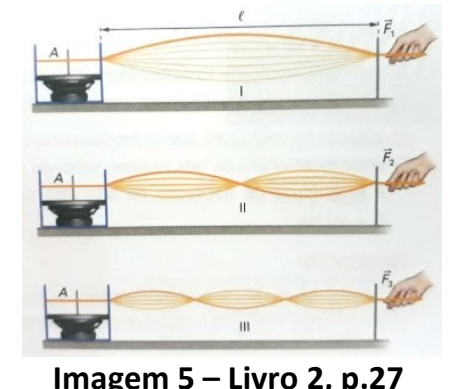

Imagem 5 - Livro 2, p.27

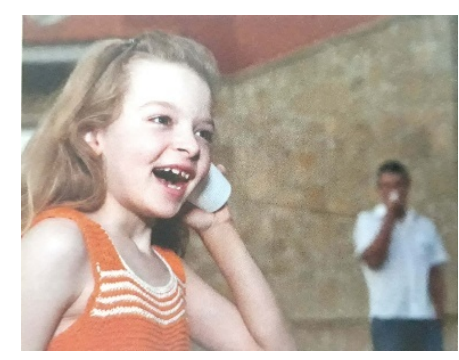

Imagem 6 - Livro 2, p.53

$\mathrm{As}^{36}$ condições de produção de um discurso, pode-se considerar tanto o contexto imediato quanto o amplo. No que concerne ao LDF 2, o contexto imediato é o autor, a equipe editorial, todas e todos sujeitos que trabalham na criação e produção do artefato em questão, a situação de publicação e produção da obra. Já o contexto amplo é o que traz para o discurso os sentidos presentificados na sociedade, na história e também mobilizantes da memória. Ambos são importantes para a constituição discursiva do discurso e são exteriores a ele. É papel do analista perceber que existe uma camada visível (o texto) e outra camada discursiva, determinada histórica e ideologicamente, e que só pode ser percebida por meio da análise.

\footnotetext{
${ }^{35}$ JODELET, Denise. As representações sociais. Ed: UERJ. Rio de Janeiro, 2001.

${ }^{36}$ ORLANDI, Eni P. Análise do discurso: princípios e procedimentos. Campinas: Pontes, 1999.
} 
$\mathrm{As}^{37}$ relações étnico-raciais, são aquelas estabelecidas entre os distintos grupos sociais, e entre indivíduos destes grupos, informadas por conceitos e ideias sobre as diferenças e semelhanças relativas ao pertencimento racial destes indivíduos e dos grupos a que pertencem. Relacionam-se ao fato de que, para cada um e para os outros, se pertence a uma determinada raça, e todas as consequências desse pertencimento.

Em outras palavras, quando estamos face a face com outra pessoa, é inegável que seu fenótipo, cor da pele, penteado e forma de vestir-se desencadeiam, de nossa parte, julgamentos sobre quem é, o que faz e até o que pensa tal pessoa. Dessa forma, informados por estereótipos, se não estivermos atentos, podemos manifestar, por palavras e gestos, discriminação, desrespeito, desqualificação. Estes julgamentos decorrem de preconceitos. Pessoas negras têm sido vítimas deles. Não poucas vezes se ouve que pessoas "desta raça", os negros, são feios, sujos, violentos ou preguiçosos ${ }^{38}$.

Essa heterogeneidade de raças, também se debruça nos sentidos do discurso no LDF, mas de forma diferente, no que tange o dito ou o silenciado ${ }^{39}$ e materializa-se por meio de diferentes vozes, já que na questão da heterogeneidade ${ }^{40}$, "as palavras são, sempre e inevitavelmente, 'as palavras dos outros'". Afirma ainda na perspectiva da psicanálise, que "sempre sob as palavras, 'outras palavras são ditas'”. ${ }^{41}$

No Livro 3, Compreendendo a Física - Volume 3- Eletromagnetismo e Física Moderna direcionado ao terceiro e quarto anos do Ensino Médio, há muitas figuras históricas e imagens de experimentos voltados para a eletromagnetismo, que ocupam maior parte do livro.

Assim como ocorreu no Livro 2, há menos imagens de pessoas e mais de mãos manipulando objetos ou demonstrando sentidos do movimento das correntes ou campos elétricos(magnéticos) (imagens 7, 8 e 9).

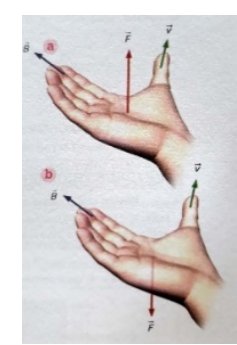

Imagem 7 - Livro 3,p.143

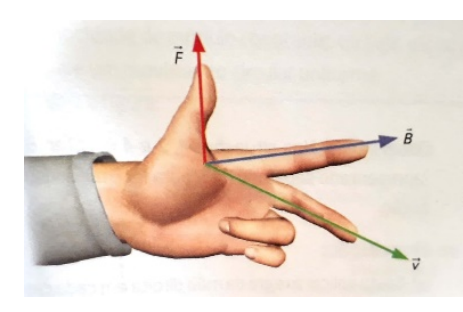

Imagem 8 - Livro 3,p.143

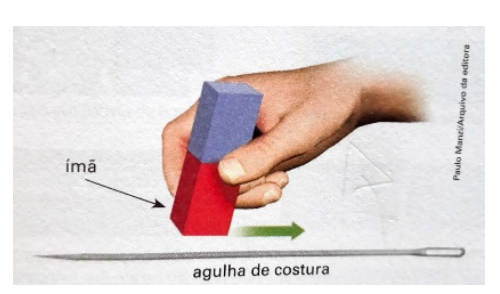

Imagem 9 - Livro 3,p.139

\footnotetext{
${ }^{37}$ VERRANGIA, D. SILVA, B.G.P Cidadania, relações étnico-raciais e educação: desafios e pontencialidades do ensino de ciências. Revista Educação e Pesquisa, V. 36, n.3 p. 705-718, set/dez, São Paulo, 2010.

${ }^{38}$ Ibdem.

${ }^{39}$ ORLANDI, Eni Puccinelli. As formas do silêncio: no movimento dos sentidos. Campinas, SP: Editora da Unicamp. $6^{\mathrm{a}}$. ed., 2013.

40 AUTHIER-REVUZ, Jaqueline. Heterogeneidade(s) enunciativa(s). Cadernos de estudos linguísticos. Campinas: n. 19. jul/dez., 1990.

41 Ibdem.
} 
Como podemos ver na tabela 3, que a quantidade de ilustração de pessoas não bancas é bem menor os no livro 3 da coleção.

\begin{tabular}{cccc} 
& \multicolumn{4}{c}{ IMAGENS DAS REPRESENTAÇÃO ÉTNICO-RACIAL DO LIVRO 3 } \\
\hline & Corpo inteiro & Parte do corpo & Total \\
\hline Brancos & 15 & 23 & 38 \\
\hline Não-brancos & 1 & 0 & 1 \\
\hline & & Total & 39
\end{tabular}

Tabela 3 - Criação dos autores.

Fazendo a análise da dimensão organizacional do Livro 1 Compreendendo a Física - Volume 1 Mecânica - direcionado ao segundo ano do Ensino Médio, foi observado que no primeiro capítulo (O que é física?), não há nenhuma menção da contribuição dos povos africanos para o conhecimento científico e tecnológico universal ou dos povos indígenas.

Apesar de fazer uma pequena abordagem sobre as origens da Física, que remontam da préhistória, não há menção das contribuições de outros povos além da visão eurocêntrica. Salvo, em um parágrafo em que tenta exemplificar o que seria um modelo em Física. Nesse parágrafo, o autor compara duas visões de mundo entre dois povos da antiguidade: os hindus e babilônicos. Para logo em seguida, voltar as ideias eurocêntricas da construção de mundo.

A Lei 10.639/03 e o Parecer CNE/CP 003/04, que introduz no campo da educação o termo "educação das relações étnico-raciais", nos convoca a refletir sobre a importância de conhecimento e vivência com povos diferentes de maneira positiva:

[...] a educação das relações étnico-raciais impõe aprendizagens entre brancos e negros, trocas de conhecimentos, quebra de desconfianças, projeto conjunto para construção de uma sociedade, justa, igual, equânime. ${ }^{42}$

Outra observação que fizemos, foi em relação aos exemplos e exercícios de fixação ao longo do livro. Eles são voltados pra a realidade Sul/Sudeste do Brasil e/ou para os países europeus e norte-americanos. Inclusive a seção de questões de vestibulares (com questões do ENEM) colocadas no livro, não contemplam a Lei 10.639/03 e 11.645/08.

No capítulo "Gravitação e Fluidos", persiste o eurocentrismo na história da ciência ao falar sobre o estudo das estrelas e planetas. Não há nenhuma citação de conhecimento de outros povos, como por exemplo, as contribuições dos antigos africanos da nação do Dogon (região do

\footnotetext{
${ }^{42}$ BRASIL. Ministério da Educação e Cultura. Diretrizes Curriculares Nacionais para Educação das Relações ÉtnicoRaciais e para o Ensino de História e Cultura Afro-brasileira e Africana. Brasília: MEC, 2004.
} 
antigo Mali) que já tinham conhecimento da existência de um "pequenino" satélite que orbitava a estrela Sirius, a Sirus B, invisível a olho nu. Os Dogon não apenas sabiam identificar as propriedades do metal que compõe o satélite Sirus B, mas tinham conhecimento da órbita de cinquenta anos de outras estrelas que orbita Sirus ${ }^{43}$.

A análise organizacional do Livro 2, Compreendendo a Física - Volume 2 Ondas, Óptica e Termodinâmica, também concentra os exemplos e exercícios nas regiões Sul/Sudeste e estrangeiras (Europa e Estados Unidos). Ao abordar os conceitos históricos sobre óptica, ignoram o conhecimento de outros povos, como os filósofos chineses antigos que estavam tão mais avançados quanto os europeus em óptica e magnetismo ${ }^{44}$. A visão eurocêntrica sobre o conhecimento científico segue todo o livro, dando um maior foco na visão formalista matemática para alguns assuntos, em comparação ao Livro 1, que consegue manter um equilíbrio entre conceitos mais reflexivos e o formalismo matemático.

A análise Organizacional do Livro 3, Compreendendo a Física - Volume 3 Eletromagnetismo e Física Moderna, segue os outros volumes, no que tange os exemplos e exercícios ao se concentrarem nas regiões Sul/Sudeste e estrangeiras (Europa e Estados Unidos).

Nesse volume, consegue fazer uma discussão mais aprofundada na epistemologia do tema do livro, trazendo novamente o equilíbrio entre os conceitos físicos e o formalismo matemático abordado no Livro 1. Porém, continua reproduzindo o eurocentrismo, ao não mencionar a contribuição do conhecimento científico de outros povos.

Não é possível pensar a implantação da Lei 10.639/03 sem considerar a necessidade de construir um projeto de educação para além do modelo colonizado e colonizador ${ }^{45}$, que distancia os sujeitos da escola e de suas próprias histórias identitárias ${ }^{46}$. Reconhecer a escola como ambiente multicultural, não é uma opção, mas uma constatação para superação deste modelo de formação (e produção de artefatos didáticos - grifo nosso) que nos impede de compreender o mundo a partir do próprio mundo em que vivemos e das epistemes que lhes são próprias ${ }^{47}$. Esse

\footnotetext{
${ }^{43}$ CUNHA, Lázaro. Contribuição dos povos africanos para o conhecimento científico e tecnológico universal. http://www. capoeiravadiacao. org/attachments/254_Contribuicao-povos-africanos\% 20Para, v. 20, p. 20o, 2010.

${ }^{44}$ SANTOS, Renato P. dos. A Parábola no Oriente: Etnofísica, Psicogênese e Multiculturalidade. $1^{\circ}$ Colóquio Intercultural-“A Comunicação entre Culturas”, ADECI-Associação Portuguesa para o Desenvolvimento, a Formação e a Investigação em Comunicação Intercultural, Almada, Portugal, p. 9-10, 2002.

${ }^{45}$ GOMES, Nilma Lino. Relações étnico-raciais, educação e descolonização dos currículos. Currículo sem Fronteiras, v. 12, n.1, p. 98-109, jan/ abr., 2003.

${ }^{46}$ HALL, S. Da Diáspora: Identidades e mediações culturais. Minas Gerais: UFMG, 2003.

${ }^{47}$ QUIJANO, Anibal. Colonialidade do poder, eurocentrismo e América Latina. In: LANDER, Edgardo (org). A colonialidade do saber, eurocentrismo e ciências sociais - Perspectivas latino-americanas. Coleção Sur Sur, CLACSO, Cidade Autônoma de Buenos Aires, Argentina. Setembro 2005. p.227-278.
} 
afastamento entre a cultura educacional e a dos meios exteriores causa consequências distintas para vários grupos de estudantes, contrariando o princípio da circularidade.

Ao analisarmos a dimensão pedagógica dos livros da coleção, vemos que o autor faz uma abordagem interessante ao inserir pequenos quadros informativos com curiosidades sobre os temas que estão sendo abordados em cada capítulo. Quando não, uma ou duas páginas inteiras que ele chama de "Atividades Práticas", em que são abordados exercícios para que os alunos possam fazer em sala de aula, em forma de experimentos qualitativos simples.

No final de cada livro, ele designa uma seção chamada Leituras Complementares, com dois subtítulos: "Sugestões de Artigos e Revistas" e "Sugestões de Livros". Nos chama a atenção que, nessa parte, o autor inclui artigos e livros que abordam contribuições de outros povos para o conhecimento científico, algo que ele poderia incluir ao longo do livro e não apenas sugerir como uma leitura complementar.

No Livro 1, por exemplo, entre os artigos indicados pelo autor, um se destaca pela importância de contemplar a Lei 11.645/08, o artigo "Mitos e Estações no Céu Tupi-guarani”, de Germano Afonso, da Revista Scientific American Brasil, mostra que os índios brasileiros, com astronomia própria, definiam o tempo de colheita, a contagem de dias, messes e anos, a chegada das chuvas e a duração das marés. Além de desenharem no céu as suas histórias, mitos e lendas e seus códigos morais. Dentre outros artigos/livros sugeridos que contemplariam a discussão afrobrasileira e indígena, o que poderia ser utilizado ao longo de toda a coleção.

No Manual do professor, o autor procura apresentar em toda a coleção conteúdos disciplinares da Física previstos nos PCN de Ciências da Natureza e nas Matrizes de Referência do Enem (MRE). Houve também a inclusão de outros conteúdos que vão além do mínimo obrigatório, como o capítulo de Física moderna e contemporânea. Na seção "Orientações oficiais para o Ensino Médio" ele cita alguns artigos das Diretrizes Curriculares Nacionais para o Ensino Médio e da MRE, mas nenhuma menção às Leis $10.639 / 03$ ou da $11.645 / 08$. Até mesmo na seção, “Atividades interdisciplinares e de contextualização", em que poderia ter uma abordagem, mesmo que sutil, sobre uma discursão afro-indígena, o autor cita que deve haver um interação entre as disciplinas do núcleo comum e complementares, dando ênfase a Língua Portuguesa, mencionando que no final do manual há um texto sobre A importância da leitura no ensino de Ciências da Natureza.

Apesar de uma sutil tentativa na parte bibliográfica do Livro do aluno em contemplar a história de outros povos, na parte do Manual para o professor, que deve atuar como recurso de formação continuada, não há indicação sobre a ERER. Isso nos indica uma espécie de silenciamento, diante de um discurso didático, que se coloca aberto à completude do outro, mas 
que por estar em um suporte textual cultural que já traz em seu bojo um direcionamento ideológico, mostra uma contradição discursiva.

$\mathrm{O}^{48}$ funcionamento do silêncio atesta o movimento do discurso que se faz na contradição. Essa contradição vem tanto do sujeito (quem produz o LDF), quanto do sentido (o discurso didático), fazendo-se no entremeio entre a ilusão de um sentido só (um DD com um único marco civilizatório) e o equívoco de todos os sentidos(ideia de que um único marco civilizatório represente uma pluralidade étnica).

Nas seções, "Sugestões para o aprimoramento profissional do professor" e "Textos de aprofundamento para o professor", são sugeridas publicações de revistas sobre Física e Ciências, com seus respectivos contatos e lista dos encontros nacionais das entidades de fomento científico, encontros e entidades de pesquisas para pesquisadoras/es do Ensino de Ciências e de Ensino de Física. Além disso, discute a importância da leitura no ensino de Ciências da Natureza. As seções restantes, são sugestões de abordagens para os temas que serão aplicados em cada unidade da coleção.

No MP, dos três volumes, em sua parte específica destinada aos professores, que fica ao final do LD, não há orientações ou propostas de trabalhos com projetos e/ou pesquisas que indiquem a preocupação com as temáticas relacionadas a cultura de diferentes povos. Não há apresentação de textos ou discussões que problematizem essa perspectiva de produção e ensino da física centrado na história, conhecimento e valores europeus. Não apresenta textos, atividades ou imagens suplementares que incorporem essas discussões, e neste sentido, também não colabora com a formação continuada dos docentes que irão utilizá-lo e nem fornecem material extra que possa lhe dar suporte.

O que podemos constatar das análises realizadas, é a falta de clareza da importância de discursivizar a História e Cultura Afro-Brasileiras, Africanas, Indígenas no discurso didático do livro de Física do Ensino Médio, dando foco à visão tradicionalista de Ciências da Natureza, mesmo tendo alguns distanciamento desse olhar ao tentar discutir uma interdisciplinalidade.

\section{Por hora... considerações finais}

Realizamos uma leitura do discurso didático do Livro Didático de Física acerca da História e Cultura Afro-Brasileiras, Africanas e Indígenas, no Ensino Médio Integrado ao Técnico utilizado no IFBA, campus Eunápolis. O corpus analisado possibilitou a problematização em relação aos

\footnotetext{
${ }^{48}$ ORLANDI, Eni Puccinelli. As formas do silêncio: no movimento dos sentidos. Campinas, SP: Editora da Unicamp. $6^{\mathrm{a}}$. ed., 2013.
} 
sentidos presentificados nos três LDF e "perceber os efeitos das práticas discursivas no contexto cultural das identidades sociais e étnicas dos grupos e minorias sociais, historicamente marginalizadas e silenciadas" ${ }^{49}$.

Para que os professores de Física possam se adequar aos currículos escolares e atender as orientações curriculares e leis para a ERER, exige uma transformação no modo de pensar e agir desse professor. O que os leva a refletir sobre como a ação educacional poderá ser feita e quais conhecimentos deverão ser ensinados. Os livros didáticos devem responder a isso, mas não podem ser considerados os únicos meios de transposição didática.

Entretanto, como pudemos constatar na coleção estudada, apesar do autor seguir os conteúdos disciplinares de Física previstos no PCN de Ciências da Natureza e nas Matrizes de Referência do Enem (MRE), há algumas lacunas que devem problematizadas diante do objetivo do estudo aqui, mas principalmente, entendemos ser importante para além de apontar equívocos, sugerirmos possibilidades de redimensionamento para uma escolha e trabalho com o LDF a favor de uma educação pela diferença e diversidade.

Dentre as coleções de livros didáticos de Física oferecidas ao IFBA - campus Eunápolis, o que motivou aos professores da instituição escolher a coleção Compreendendo a Física, Alberto Gaspar - 3. ed. - São Paulo: Ática, 2016, foi a forma com que o livro aborda os assuntos e como é organizado, procurando contemplar as Orientações Curriculares para o Ensino Médio (OCEM). Mas como ele não contempla de forma efetiva a Educação para as Relações Étnico-raciais ao longo do livro, salvo poucos materiais sugeridos pelo autor na seção Leituras Complementares, que abordam o tema, indicamos que as/os professoras/es podem utilizar exemplos (ou exercícios) que possam suprir essa ausência e inclusive, colocar como objeto de estudo em suas aulas, essa ausência, direcionando uma discussão sobre o silenciamento e invisibilização dos povos negros e indígenas, sendo que esses povos representam a nossa história e ancestralidade.

Os exercícios de fixação e de vestibulares, escolhidos pelo autor dos LDF analisados, não condizem com o cotidiano do aluno negro, indígena e/ou periférico. O professor pode incluir na aula, ou em lista de exercícios (que podem ser também alternadas ou substituídas por outros recursos), que envolvam questões sociais de alunos negros e/ou indígenas nos temas abordados em sala de aula. Como Eunápolis é localizada próximo a reservas indígenas, e há muitos alunos negros vivendo na cidade, o professor poderá construir exemplos que o estudante possa identificar a sua realidade, tornando o assunto mais interessante.

\footnotetext{
${ }^{49}$ SANTOS, M. F. dos; SOUZA, M. M. Pedagogia ou Pretagogia: Movimentos de sentidos no discurso pedagógico em um curso de licenciatura em Matemática. Revista Espaço Acadêmico, n. 207, ano XVIII, agosto, Paraná , 2018.
} 
Uma forma interessante de abordagem é por meio da Astronomia. Pois, é ${ }^{50}$ uma ferramenta poderosa para os/as professores/as, por evocar a curiosidade inata dos estudantes. O pioneirismo na observação dos astros pelos povos indígenas e africanos, os ajudarão na observação da influência dos astros na vida cotidiana, principalmente na agricultura. E com a chegada dos africanos escravizados no Brasil, houve uma vinculação do conhecimento entre negros e índios, promovendo uma riqueza cultural importante para Brasil.

O professor pode aproveitar o tema de astronomia e abordar outros temas da Física que mencionam o resultado da mistura africana e indígena. E o mesmo autor, diz ainda:

Ao traçar a evolução histórica da utilização dos recursos naturais e do ambiente, principalmente com base nos conhecimentos desses povos, como: a utilização do solo para a produção e obtenção de alimentos, a pouca geração de resíduos orgânicos e as técnicas de construção com materiais renováveis, recursos esses que impactavam pouco o ambiente. ${ }^{51}$

Podemos constatar que o projeto didático da coleção analisada, não se movimenta para a efetivação de fato da legislação específica do Ensino de História e Cultura Afro-brasileira na rede regular de educação básica. Percebemos que o interesse maior é contemplar a interdisciplinaridade e por força de lei apenas, de forma pulverizada e sumária, sinalizar a contribuição de povos negros e indígenas na produção de conhecimento, o que também nos faz criticar as formas de avaliação desses livros, para que na futuras políticas, a questão relacionada à diferença e diversidade seja melhor exigida como ponto de referência para a aprovação dos LD.

A outra possibilidade é a leitura crítica deste material didático com os estudantes. A discussão de quais conteúdos compõem cada um dos LD e o porquê desta seleção e não de outra. Problematizar a ausência de determinados conhecimentos na organização desses livros e a preponderância de um visão eurocentrada. Indicar e questionar o uso e abuso das imagens nos LD que não incorporam a diversidade étnica e cultural brasileira, privilegiando os sujeitos brancos. Reorganizar as atividades propostas, a partir de críticas pela invisibilidade dos sujeitos afrodescendentes e indígenas que carregam, incorporando-os, bem como suas realidades. Em outras palavras, fazer uso deste material a partir de uma "partitura" composta pelo professor que se suleie por uma nova proposta para o ensino da disciplina.

Isso obriga uma ampliação no plano conceitual e epistemológico do que significa construir uma proposta de fato didática sob a perspectiva racial, que considere para o ensino de Física, as

\footnotetext{
${ }^{50}$ ZANATTI, A.W.; SIQUEIRA, J. F. R. Etnoastronomia: um resgate das culturas africana e indígena. In: SIMPÓSIO NACIONAL DE EDUCAÇÃO EM ASTRONOMIA, 2., 2012, São Paulo(SP). Anais.

${ }^{51}$ Ibdem.
} 
epistemologias africanas e indígenas que potencializam a descolonização deste artefato cultural e, em sua prática, garantem o reconhecimento do sujeito com sua vida social e cultural. Uma possibilidade e que pode ser também tomada como referência do LDF, é a Pretagogia.

A Pretagogia é um referencial teórico-metodológico curricular de matriz africana criado e nomeado de Pretagogia: pedagogia de preto para preto e branco ${ }^{52}$, que entendemos ser importante para desenvolver a formação de professores/as, bem como para ter como proposta, para direcionamento para a escolha e para o trabalho com o livro didático, em prol das diferenças étnicas, raciais e culturais, em uma abordagem afrocentrada de educadores/as ${ }^{53}$.

$\mathrm{Na}^{54}$ compreensão de uma cosmovisão africana e embasada em autores como Bâ (1982), Munanga (2009), Oliveira (2006) dentre outros e outras, nos apresenta os princípios da Pretagogia:

\begin{abstract}
o autorreconhecer-se afrodescendente, assumindo uma postura autoafirmativa e lembrando sempre a importância da raiz africana para nossa constituição como pessoa; a apropriação da ancestralidade, pois fazemos parte de linhagens que envolvem os antepassados e os mortos. Implica, sobretudo, em valorizar os antepessados, a história dos mais velhos e o aprendizado dos seus ensinamentos; é ainda o que nos fornece uma identidade coletiva, propiciando um sentimento de pertencimento; a religiosidade de matriz africana como base e entrelaçamento de todos os saberes e de todas as dimensões do conhecimento, que gera uma forma de pensar, de estar e de agir no mundo, marcada pela fé inquebrantável na força vital que perpassa o universo (axé); o reconhecimento da sacralidade como dimensão que perpassa todos os saberes das culturas de matriz africana, levando a uma postura de identificação, respeito e espiritualidade para com a natureza: "[...] o que dá identidade a um grupo são as marcas que ele imprime na terra, nas árvores, nos rios" (SODRÉ, 1988,p.22); o corpo como fonte primeira de conhecimento e produtor de saberes, altar espiritual que faz parte do território natureza, e, como tal, elemento da sacralidade; a tradição oral valorizando o conhecimento que é repassado de modo transversal por meio da oralidade, da vivência e da experiência e por todas as formas de falar e vibração dos seres da natureza; o princípio de circularidade na relação entre os seres, os tempos e as coisas, a interconectividade do ethos ubuntu reforça esse princípio, afirmando a relação comunitária que nos perpassa, pois "[...] uma pessoa é uma pessoa por meio de outras pessoas" (LOUW, 2010); o entendimento da noção de território como espaço-tempo socialmente construído e perpassado da história de várias gerações e formado por uma complexa rede de relações sociais, espaço este perpassado de sacralidade; a compreensão do lugar social historicamente atribuído ao negro, marcado pelo racismo estrutural, o que nos exige posturas de desconstrução do estigma forjado secularmente ${ }^{55}$.
\end{abstract}

A Pretagogia, as leis 10.639/03 e 11.645/08, as Diretrizes Curriculares Nacionais para ERER, as teorias multi e pruriculturais e de(s)coloniais, são importantes e necessários meios para a

\footnotetext{
${ }^{52}$ SILVA, Geranilde Costa e. Pretagogia: construindo um referencial teórico- metodológico, de base africana, para a formação de professores/as.. Tese (Doutorado em Educação) - Universidade Federal do Ceará, Faculdade de Educação, Programa de Pós-Graduação em Educação Brasileira, Fortaleza, 2013. 242 f.

53 PETIT, Sandra Haydée. Pretagogia: Pertencimento, Corpo-Dança Afroancestral e Tradição Oral Africana na Formação de Professoras e Professores - Contribuições do Legado Africano para a Implementação da Lei 10639/03.Fortaleza, EdUECE, 2015.

${ }^{54}$ Ibdem.

${ }^{55}$ Ibem.
} 
formação e informação por uma escolha pela diferença na escola e na escolha de seus artefatos culturais de uso didático. A formação é importante também, para que sejam pensadas propostas interdisciplinares que superem o folclore com a questão da ERER, para uma trabalho político e respeitoso que protagonize os diferentes povos. A Filosofia e a História da Ciências também são importantes meios para a construção de uma visão de conhecimento humanizada, também referenciada em documentos curriculares nacionais como a OCEM e por diversos pesquisadores/pesquisadoras da área da do Ensino de Física.

Entendemos que este trabalho contribuirá para refletir as concepções representadas nos livros didáticos, especialmente da área de Física e das Ciências da natureza como um todo que legitimam a naturalização do discurso eurocentrado, com vistas a uma ERER positiva.

\section{Referências}

AIRES, Joanez A. Integração Curricular e Interdisciplinaridade: sinônimos? Educação \& Realidade, Porto Alegre, v. 36, n.1, p. 215-230, jan./abr., 2011.

ANDRÉ, M. da C.. O Ser Negro - A construção da subjetividade em afro brasileiros. Brasília: LGE Editora, 2008.

AUTHIER-REVUZ, Jaqueline. Heterogeneidade(s) enunciativa(s). Cadernos de estudos linguísticos. Campinas: n. 19. jul/dez., 1990.

BENETTI, Marcia. Análise do discurso em jornalismo: estudo de vozes e sentidos. In: LAGO, Cláudia; BENETTI, Marcia (org.). Metodologia de pesquisa em jornalismo. Petrópolis: Vozes, 2007. BRASIL, Ministério da Educação. Diretrizes Curriculares Nacionais para a Educação das Relações Étnico-raciais e para o Ensino de História e Cultura Afro-brasileira e Africana.

BRASIL. Lei 10639/03. Altera a Lei no 9.394, de 20 de dezembro de 1996, que estabelece as diretrizes e bases da educação nacional, para incluir no currículo oficial da Rede de Ensino a obrigatoriedade da temática "História e Cultura Afro-Brasileira", e dá outras providências. Brasília: Ministério da Educação, 2003.

BRASIL. Lei 11.645/08 de 10 de Março de 2008. Diário Oficial da União, Poder Executivo, Brasília.

BRASIL. Ministério da Educação e Cultura. Diretrizes Curriculares Nacionais para Educação das Relações Étnico-Raciais e para o Ensino de História e Cultura Afro-brasileira e Africana. Brasília: MEC, 2004.

Brasília: MEC, 2004. BRASIL. Lei n. o 10.639, de 09.01.03: altera a Lei 9394/96 para incluir no currículo oficial da Rede de Ensino a obrigatoriedade da temática "História e cultura afrobrasileira". Brasília: [s.n.], 2003.

CANEN, A.; MOREIRA, A. F. B. (orgs.). Ênfases e Omissões no currículo. Campinas, SP: Papirus, 2001.

CAVALLEIRO, Eliane (Org.). Racismo e anti-racismo na educação. Repensando nossa escola. São Paulo: Summus, 2001.

CUNHA, Lázaro. Contribuição dos povos africanos para o conhecimento científico e tecnológico 
universal. Disponível em:https://www.trabalhosfeitos.com/ensaios/Contribui\%C3\%A7\%C3\%B5esDos-Povos-Africanos/706021.html. Acessado em: 03/08/2018.

D’AMBROSIO, Ubiratan. Etnomatemática: elo entre as tradições e a modernidade. Coleção Tendências em Educação Matemática .Belo Horizonte: Autêntica, 2001.

DOMINGUINI, L. Fatores Que Evidenciam A Necessidade De Debates Sobre O Livro Didático. Trabalho apresentado em V CINFE- Congresso Internacional de Filosofia e Educação, Caxias do Sul, mai. 2010.

FARIA, L. M.; MORAES, I. J. ; BARRIO, J. B. M. A Visão De Ciência Em Livros Didáticos Utilizados Por Professores De Física Do Ensino Médio. Trabalho apresentado em XVIII SNEF- Simpósio Nacional de Ensino de Física, Vitória, 2009.

FERRO, Marc. Trad. de Wladimir Araujo. A manipulação da história no ensino e nos meios de comunicação. 2. ed. São Paulo: Ibrasa, 1983.

FILHO, J. Camilo dos; GAMBOA, Silvio Sánchez. Pesquisa educacional: quantidade-qualidade. 4. ed. São Paulo: Cortez, p.13-59, 2001.

FREIRE, Paulo. Educação e atualidade brasileira. São Paulo: Instituto Paulo Freire, 2001.

GARCIA, P. S.; BIZZO, N. A pesquisa em livros didáticos de ciências e as inovações no ensino. Revista Educação em Foco, v. 13, n. 15: p. 13-35, Belo Horizonte, jul. 2010.

GASPAR, Alberto. Compreendendo a Física - Eletromagnetismo e Física Moderna . 3. ed. v.3. São Paulo: Ática, 2016.

GASPAR, Alberto. Compreendendo a Física - Mecânica. 3. ed. v.1. São Paulo: Ática, 2016.

GASPAR, Alberto. Compreendendo a Física - Ondas, Óptica e Termodinâmica. 3. ed. v.2. São Paulo: Ática, 2016.

GOMES, Nilma Lino. Relações étnico-raciais, educação e descolonização dos currículos. Currículo sem Fronteiras, v. 12, n.1, p. 98-109, jan/ abr., 2003.

HALL, S. Da Diáspora: Identidades e mediações culturais. Minas Gerais: UFMG, 2003.

JODELET, Denise. As representações sociais. . Rio de Janeiro :Ed. UERJ, 2001.

MEGID NETO J. ; LOPES, B. B. G.; Livros Didáticos De Física E As Inovações Da Pesquisa Em Educação Em Ciências, 2009. Trabalho apresentado em XVIII SNEF-Simpósio Nacional de Ensino de Física, Vitória, 2009.

NOSELLA, Maria de Lourdes Chagas Deiro. As belas mentiras: a ideologia subjacente aos textos didáticos. 8. ed. São Paulo: Moraes, 1978.

OLIVEIRA, M.M.D.; OLIVEIRA, A.F.B. (Orgs.) Livros didáticos de História: escolhas e utilizações. Natal, RN: EDUFRN, 2009.

OLIVEIRA, Margarida Maria Dias de. Livros didáticos de história: pesquisa,ensino e novas utilizações deste objeto cultural. IN: Série: o livro didático em questão. Salto para o futuro. Rio de Janeiro: Empresa Brasileira de Comunicação, (08/05/ 2006-12/05/2006).

ORLANDI, Eni P. Análise do discurso: princípios e procedimentos. Campinas: Pontes, 1999.

ORLANDI, Eni P. Interpretação; autoria, leitura e efeitos do trabalho simbólico. 4ạ Ed. Campinas: Pontes, 2004.

ORLANDI, Eni Puccinelli. As formas do silêncio: no movimento dos sentidos. Campinas, SP: Editora da Unicamp. 6a. ed., 2013.

ORLANDI, Eni Puccinelli. Gestos de leitura: da história no discurso. (Org.) et al. 4ed. Campinas, SP: Editora da Unicamp, 2014. 
PETIT, Sandra Haydée. Pretagogia: Pertencimento, Corpo-Dança Afroancestral e Tradição Oral Africana na Formação de Professoras e Professores - Contribuições do Legado Africano para a Implementação da Lei 10639/03.Fortaleza: EdUECE, 2015.

QUIJANO, Anibal. Colonialidade do poder, eurocentrismo e América Latina. In: LANDER, Edgardo (org). A colonialidade do saber, eurocentrismo e ciências sociais - Perspectivas latino-americanas. Coleção Sur Sur, CLACSO, Cidade Autônoma de Buenos Aires, Argentina. Setembro 2005. p.227278.

ROCHA, H.A.B.; REZNIK, L.; MAGALHÃES, M.S. (Orgs.) A história na escola: autores, livros e leituras. Rio de Janeiro: Ed. FGV, 2009.

SANTOS, M. F. dos; SOUZA, M. M. Pedagogia ou Pretagogia: Movimentos de sentidos no discurso pedagógico em um curso de licenciatura em Matemática. Revista Espaço Acadêmico, n. 207, ano XVIII, agosto, Paraná , 2018.

SANTOS, Renato P. dos. A Parábola no Oriente: Etnofísica, Psicogênese e Multiculturalidade. 1은 Colóquio Intercultural-“A Comunicação entre Culturas”, ADECI-Associação Portuguesa para o Desenvolvimento, a Formação e a Investigação em Comunicação Intercultural, Almada, Portugal, p. 9-10, 2002.

AFONSO, Germano. Mitos e estações no céu tupi-guarani. Scientific American Brasil, v. 4, n. 45, p. 46-55, 2006.

SILVA, Geranilde Costa e. Pretagogia: construindo um referencial teórico- metodológico, de base africana, para a formação de professores/as. Tese (Doutorado em Educação) - Universidade Federal do Ceará, Faculdade de Educação, Programa de Pós-Graduação em Educação Brasileira, Fortaleza, 2013.

SILVA, M. L.(org.) Ciência, raça e racismo na modernidade. Santa Cruz do Sul: EDUNISC, 2009.

SILVA, Paulo Vinicius Baptista. Racismo em livros didáticos: estudos sobre negros e brancos em livros de língua portuguesa. Belo Horizonte: Autêntica, 2008.

VERRANGIA, D. SILVA, B.G.P Cidadania, relações étnico-raciais e educação: desafios e pontencialidades do ensino de ciências. Revista Educação e Pesquisa, V. 36, n.3 p. 705-718, set/dez, São Paulo, 2010.

ZANATTI, A.W.; SIQUEIRA, J. F. R. Etnoastronomia: um resgate das culturas africana e indígena. In: SIMPÓSIO NACIONAL DE EDUCAÇÃO EM ASTRONOMIA, 2., 2012, São Paulo(SP). Anais.

Mariana Fernandes dos Santos: Doutoranda em Ensino, Filosofia e História das Ciências (UFBA). Mestra em Estudo de Linguagens(UNEB).Especialista em Ensino de Língua Portuguesa e Literatura (FACSABA).Especialista em Educação a Distância(UNEB).Possui graduação em Letras-Vernáculas (UNEB). Atualmente é Professora de Língua Portuguesa , Literaturas, Teoria e Prática textual do Instituto Federal de Educação, Ciência e Tecnologia da Bahia- IFBA, atuando nos níveis de Ensino Médio Integrado ao Técnico, Técnico Subsequente, Graduação e Pós-Graduação. É professora colaboradora no Programa de PósGraduação em Linguística Aplicada ao Ensino de Língua Portuguesa, em nível de especialização (UNEB). Desenvolve pesquisas nas áreas de Linguagem e tecnologia, Currículo, Linguagem e Educação, Formação docente,Ensino de língua materna, Gêneros textuais e discursivos, Língua(gem) em áreas diferentes das Letras, Língua Portuguesa no Ensino Superior, Letramentos, Análise do discurso de linha francesa, Linguística Aplicada, Multi e Interculturalidade, Gênero e Diferença. 
Nathalia Helena Alem: Minha formação inicial é em História, Licenciatura Plena pela Universidade Federal de Minas Gerais. Possuo mestrado em Educação pela Universidade Federal de Sergipe e doutorado em Educação pela Universidade Federal de Minas Gerais. Venho trabalhado com temas relacionados ao Ensino de História, Ensino de História na Educação Técnico Profissional e História da Educação. Desde 1996 sou professora do Instituto Federal de Educação, Ciência e Tecnologia da Bahia/Campus de Eunápolis, onde ministro aulas nos níveis médio, superior e em cursos de especialização.

Jorge Ferreira Dantas Junior: Doutorando em Física (UFBA) na área de Cosmologia. Mestre em Física (UFBA) na área de Cosmologia. Possui graduação em Licenciatura e Bacharelado em Física (UFBA). Atualmente é Professor de Física do Instituto Federal de Educação, Ciência e Tecnologia da Bahia- IFBA, atuando nos níveis de Ensino Médio Integrado ao Técnico, Técnico Subsequente, Graduação. Tem interesse nas áreas de pesquisa: Ensino de Física, Cosmologia, Diversidade e Diferença.

Artigo recebido para publicação em: Outubro de 2018.

Artigo aprovado para publicação em: Novembro de 2018.

Odeere: Revista do Programa de Pós-Graduação em Relações Étnicas e Contemporaneidade - UESB. ISSN: 2525-4715 - Ano 2018, Volume 3, número 6, Julho - Dezembro de 2018. 